Aplikasi Geolistrik 2D ...

\title{
APLIKASI GEOLISTRIK 2D UNTUK IDENTIFIKASI BIDANG GELINCIR STUDI KASUS DAERAH LERENG NGLAJO, CEPU
}

\author{
Rizal Taufiqurrohman, Diptya Mas Nugraha, Ayi Syaeful Bahri
}

Teknik Geofisika, Fakultas Teknik Sipil, Lingkungan dan Kebumian, Institut Teknologi Sepuluh Nopember Surabaya, e-mail : syaeful_b@geophysic.its.ac.id

\begin{abstract}
Abstrak. Lereng Nglajo, Cepu, terletak ketinggian 67-68 mdpl. Menurut pengamatan warga, kondisi aspal jalan pada daerah penelitian selalu diperbaiki setiap tahun. Jalan ini berseberangan dengan lereng pada bagian barat. Tidak hanya itu, kondisi pagar rumah sebelah timur jalan juga mengalami perubahan. Tujuan dari penelitian ini adalah untuk mengetahui seberapa dalam bidang gelincir dan jenis longsorannya. Bentuk slidding akan ditampilkan secara 2D dan 3D sehingga dapat dibedakan mana batuan dasar dan batuan lepas/rombakan. Metode yang digunakan berupa metode geolistrik konfigurasi wenner dengan panjang lintasan bagian utara selatan adalah $100 \mathrm{~m}$ dan bagian barat timur adalah $82,5 \mathrm{~m}$. Hasil dari pengolahan data akan menunjukkan model topografi, , model bidang gelincir yang diinterpretasikan dengan kondisi daerah dan geologi regional setempat. Hasil analisis menunjukkan bahwa daerah ini memiliki potensi longsor jenis rayapan (Creep) dan nilai resistivitas untuk lempung rombakan adalah < 2 ohm-m dan lempung kompak $>2$ ohm-m sehingga dapat diketahui kedalaman bidang gelincir dari permukaan yaitu 1 hingga 5,8 m. Hasil penelitian tersebut dapat menjadi pendugaan sementara untuk perencanaan pembangunan lebih lanjut pada daerah Lereng Nglajo.
\end{abstract}

Kata Kunci : Kedalaman bidang gelincir, Lereng Nglajo, Resistivitas, Rayapan

Abstract. The Nglajo Slope, in Cepu, has elevation about 67-68 meters above sea level. According to the residents' observation, road asphalt condition in research area is always improved every year. This road is across to the western slopes. Not only that, the condition of the fence of the house east of the road also changed. The purpose of this research is to know how deep the field of slip and type of avalanche. Slidding form will be displayed in 2D and 3D so it can be distinguished where the bedrock and rock loose / dry rock. The method used geoelectric with wenner configuration method with the length of the northern part of the south is $100 \mathrm{~m}$ and the east west is $82.5 \mathrm{~m}$. The results of the data processing will show the topographic model, the slip field model interpreted by local regional and geological conditions. The result of the analysis showed that this area has the potential of landslide type of creep and resistivity value for clay is $<2 \mathrm{ohm}-\mathrm{m}$ and compact clay $>2 \mathrm{ohm}$-so that it can be known the depth of the slip surface from 1 to $5.8 \mathrm{~m}$. The results of such research may be a temporary estimate for further development planning on the Nglajo Slope area.

Keywords : Creep, Depth of Slip Slopes, The Nglajo Slope, Resistivity

\section{PENDAHULUAN}

Jalan aspal yang terletak di kecamatan Nglajo, Cepu telah mengalami kerusakan yang terjadi setiap tahun. Kerusakan tersebut bukan dari dampak laju kendaraan yang melintasinya namun karena jalanan aspal tersebut retak. Menurut sumber informasi ESDM, setiap tahun pemerintah mengeluarkan dana untuk pembiayaan perbaikan jalan. Tidak hanya pada jalannya saja, namun pada pagar-pagar perumahan di sekitarnya juga mengalami kemiringan dan juga retak pada bagian bawah. Akibat permasalahan ini, maka dilakukanlah identifikasi bawah permukaan terhadap kerusakan yang terjadi. Identifikasi bawah permukaan akan digunakan dengan metode geolistrik tahanan jenis sehingga dapat diketahui bentuk kemiringan lereng serta kedalaman bidang gelincirnya pada daerah aspal tersebut. Metode ini sudah terbukti dapat digunakan untuk mengidentifikasi bidang gelincir (Utama dkk., 2016). Penelitian ini dapat menjadi rekomendasi pemasangan beton dan aspal penguat jalan yang lebih tepat dan optimal. 


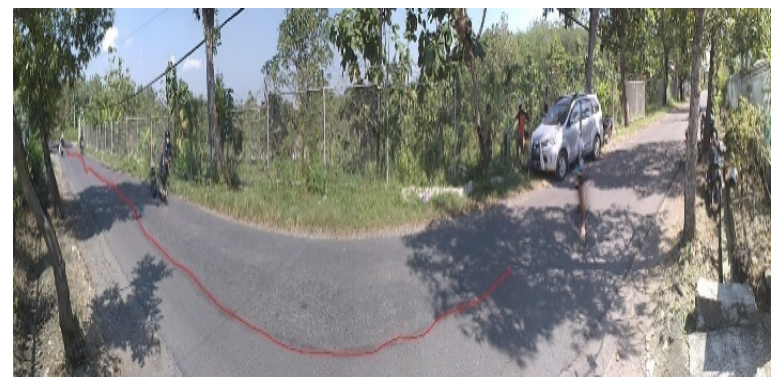

Gambar 1 Kondisi aspal di sebelah timur daerah pengukuran. Terlihat aspal ambles pada garis warna merah (Penulis, 2016).

\section{TINJAUAN PUSTAKA}

\section{Geologi Regional}

Geologi regional Nglajo termasuk dalam lembar Bojonegoro (Pringgoprawiro \& Sukido, 2012). Pada daerah penelitian kali ini terletak pada kecamatan Nglajo dengan kode formasi QTI (gambar 2) yaitu Formasi Lidah yang terdiri dari litologi batuan lempung, bersisipan dengan batuan gamping dan abut pasir. Batu lempung memiliki ciri-ciri sebagai berikut : berwarna kelabu tua hingga kebiruan; lunak;gampingan dan napalan, pasiran halus hingga sangat halus; pejal, setempat berkembang struktur perairan.

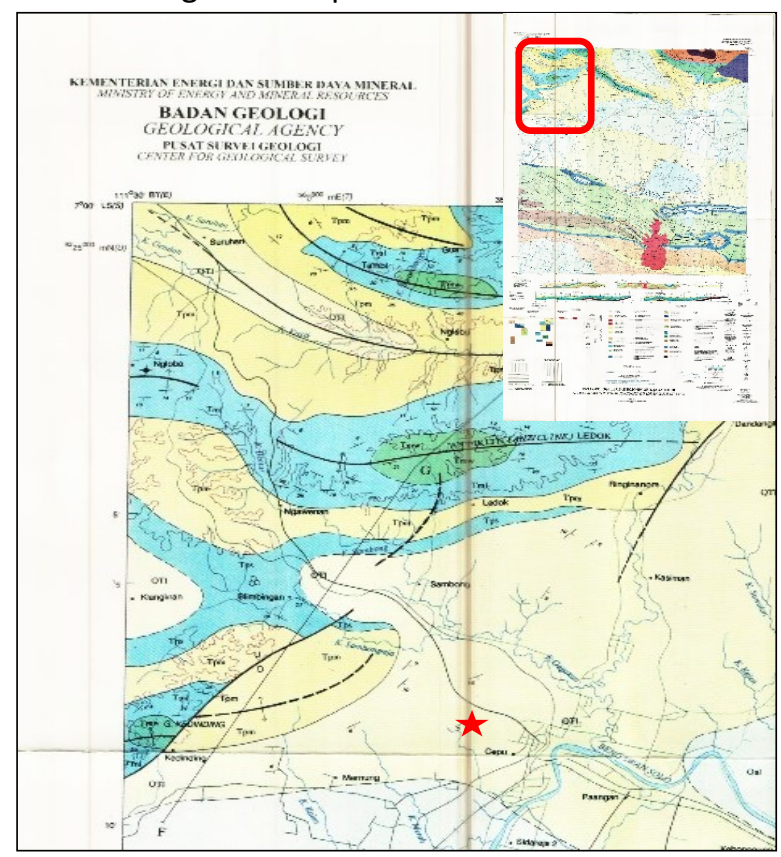

Gambar 2 Peta geologi regional lembar bojonegoro

(Pringgoprawiro \& Sukido, 2012). Kotak merah merupakan daerah yang di perbesar dan tanda bintang merah merupakan lokasi penelitian.

\section{Sifat Kelistrikan Batuan dan Mineral}

Sifat kelistrikan batuan akan ada ketika batuan tersebut dialiri arus listrik. Sifat kelistrikan pada batuan terletak pada kemampuan batuan untuk dapat menghantarkan dan menghambat arus listrik, atau biasa disebut dengan konduktivitas dan tahanan jenis. Kedua nilai tersebut konstan pada batuan dan mineral. Berdasarkan kemampuan menghantarkan arus listrik, sifat tahanan jenis batuan dibagi menjadi 3 bagian sebagai berikut :
a) Resistif
: resistivitas $>10^{7} \Omega \mathrm{m}$
b) Semikonduktif : resistivitas $1-10^{7} \Omega \mathrm{m}$
c) Konduktif : resistivitas $10^{-8}-1 \Omega \mathrm{m}$

Tabel 1. Tabel Resistivitas Batuan (Loke, 2015)

\begin{tabular}{lcc}
\hline \multicolumn{1}{c}{ Material } & $\begin{array}{c}\text { Resistivitas } \\
(\Omega \mathrm{m})\end{array}$ & $\begin{array}{c}\text { Konduktivitas } \\
\text { (Siemens.m) }\end{array}$ \\
\hline Branit & $5 \times 10^{3}-10^{6}$ & $10^{-6}-2 \times 10^{-4}$ \\
Basalt & $10^{3}-10^{6}$ & $10^{-6}-10^{-3}$ \\
Slate & $6 \times 10^{2}-4 \times 10^{7}$ & $2.5 \times 10^{-8}-1.7 \times 10^{-3}$ \\
Marble & $10^{2}-2.5 \times 10^{8}$ & $4 \times 10^{-9}-10^{-2}$ \\
Quartzite & $10^{2}-2 \times 10^{8}$ & $5 \times 10^{-9}-10^{-2}$ \\
\hline \multicolumn{3}{c}{ Batuan Sedimen } \\
\hline Batupasir & $8-4 \times 10^{3}$ & $2.5 \times 10^{-4}-0.125$ \\
Batulempung & $20-2 \times 10^{3}$ & $5 \times 10^{-4}-0.05$ \\
Batugamping & $50-4 \times 10^{2}$ & $2.5 \times 10^{-3}-0.02$ \\
\hline \multicolumn{3}{c}{ Tanah dan Air } \\
Lempung & $1-100$ & $0.01-1$ \\
Aluvial & $10-800$ & $1.25 \times 10^{-3}-0.1$ \\
Air Tanah & $10-100$ & $0.01-0.1$ \\
Air Laut & 0.2 & 5 \\
\hline
\end{tabular}

Tabel 1 menunjukkan nilai resistivitas dan konduktivitas yang dimiliki oleh batuan dan material. Setiap batuan dan material memiliki penyusun yang berbeda sehingga nilai sifat kelistrikan yang dimiliki pun berbeda. Nilai-nilai di atas memiliki rentang atas dan rentang bawah yang menunjukkan bahwa pada kondisi tertentu, nilai resistivitas atau konduktivitas yang dimiliki batuan tersebut bisa berbeda namun masih dalam rentang tersebut. Faktor yang menyebabkan muncul rentang tersebut bisa dari saturasi fluida dalam batuan ataupun campuran pada batuan tersebut. 


\section{Metode Resistivitas 2D}

Metode Resistivitas 2D merupakan metode geofisika aktif yang memiliki konsep mengalirkan arus listrik ke bawah permukaan bumi dan mengukur beda potensial titik tertentu. Metode ini memanfaatkan sifat kelistrikan batuan perlapisan bumi untuk mengetahui variasi tahanan jenis bawah permukaan bumi baik secara horizontal maupun secara vertikal (Telford et.al, 1990).

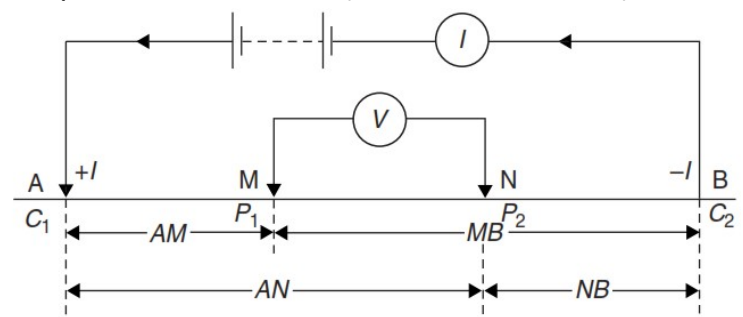

Gambar 3 Konsep Resistivitas 2D (Reynolds, 2011)

Gambar 3 menjelaskan tentang konsep dasar pengukuran metode Resistivitas 2D dengan menggunakan dua sumber arus (AB) dan dua pengukur tegangan (MN). Untuk dapat mengetahui nilai resistivitas semu dari satu pengukuran tersebut, digunakan rumus di bawah ini :

$$
\rho=R \cdot 2 \pi\left\{\left(\frac{1}{M M}-\frac{1}{W B}\right)-\left(\frac{1}{M}-\frac{1}{W B}\right)\right\}^{-1}
$$

Bentuk konfigurasi yang digunakan dalam penelitian ini ialah Wenner-Schlumberger. Konfigurasi ini merupakan hasil perpaduan antara konfigurasi Wenner dengan Schlumberger. Posisi pemasangan elektroda konfigurasi WennerSchlumberger seperti pada di bawah ini.

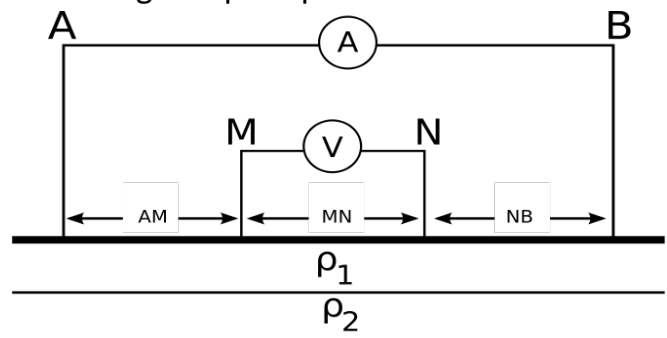

Gambar 4 Pemasangan Elektroda Konfigurasi Wenner ( (Fralama, 2017)

Nilai faktor geometri (K) dari konfigurasi wenner ialah sebagai berikut :

$$
K=\pi n(x+1) a
$$

Keunggulan yang dimiliki konfigurasi WennerSchlumberger ialah mampu memetakan distribusi nilai resistivitas secara lateral dalam kehomogenan sekaligus mendeteksi adanya non-homogenitas lapisan secara vertikal. Penetrasi kedalaman lebih baik bila dibandingkan dengan konfigurasi Wenner (Reynolds, 2011).

\section{METODOLOGI PENELITIAN}

Lokasi penelitian lapangan berada di jalan Taman Bahagia, Nglajo Kabupaten Cepu dengan koordinat (-7.148138783, 111.5867004739), pada Gambar 5 Garis merah merupakan Line 1, garis kuning merupakan line 2 , dan garis biru merupakan line 3.

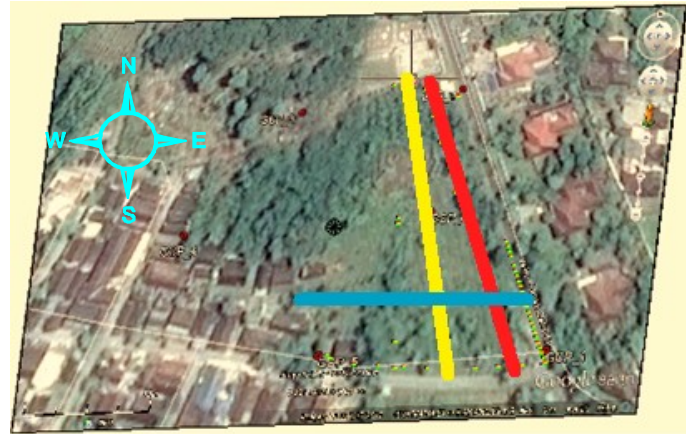

Gambar 5 Lokasi Penelitian

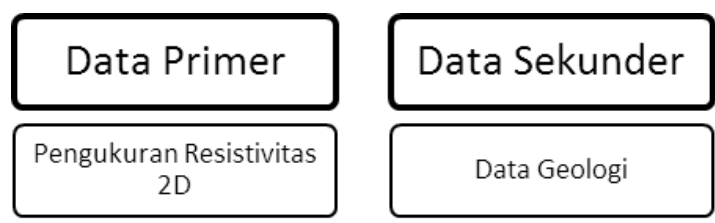

Gambar 6. Data Penelitian

Data yang digunakan dalam penelitian ini meliputi data primer dan data sekunder, sedangkan data sekunder yang digunakan merupakan data geologi. Pengukuran Resistivitas 2D menggunakan 56 elektroda dengan spasi 0.5 meter dan total panjang lintasan 100 meter untuk garis kuning dan $82,5 \mathrm{~m}$ untuk garis merah dan hijau.

Peralatan yang digunakan dalam pengukuran lapangan diantaranya :
- 1 set SuperStinig R8
- 1 set Meteran
- 1 set Palu
- 60 buah Elektroda
- 1 buah GPS
- Multimeter Digital
- 2 buah Aki

\section{HASIL DAN PEMBAHASAN}

Penampang Resistivitas 2D 
Untuk penampang utara-selatan:

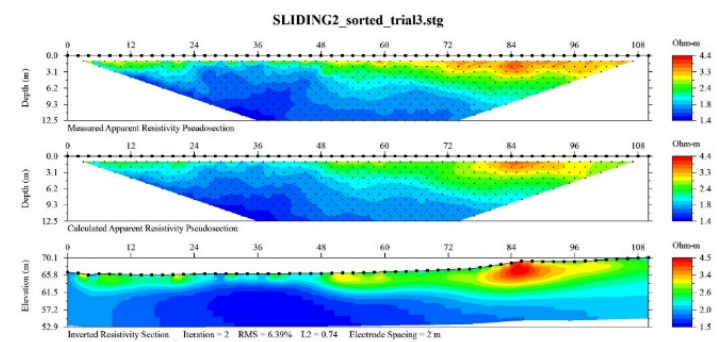

Gambar 7 Tampilan hasil pengolahan lintasan 1 dengan AGI Earthlmager 2D

Pada lintasan 1 digunakan lintasan sepanjang $110 \mathrm{~m}$ dengan arah lintasan N345E. Penampang bawah permukaan yang dihasilkan memiliki tingkat kesalahan sebesar 6,39\% dengan iterasi sebanyak 2 kali. Pada penampang resistivitas bawah permukaan sebenarnya didominasi oleh warna biru tua yang memiliki nilai resistivitas dibawah $1,9 \Omega \mathrm{m}$ dan warna hijau muda dengan nilai resistivitas 2,6 $\Omega \mathrm{m}$.

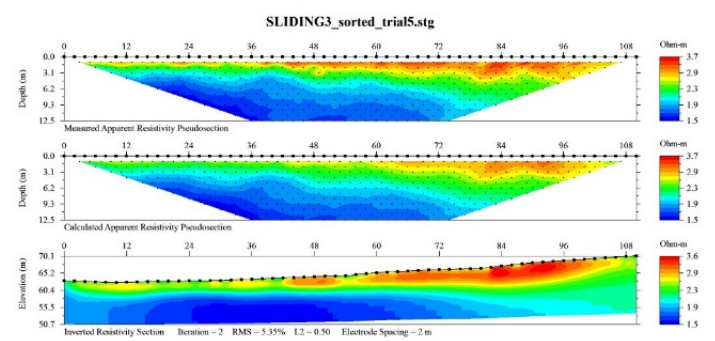

Gambar 8 Tampilan hasil pengolahan lintasan 3 dengan AGI EarthImager 2D

Pada lintasan 2 digunakan lintasan sepanjang $110 \mathrm{~m}$ dengan arah lintasan N355E. Penampang bawah permukaan yang dihasilkan memiliki tingkat kesalahan sebesar 5,35\% dengan iterasi sebanyak 2 kali. Pada penampang resistivitas bawah permukaan sebenarnya didominasi oleh warna biru tua yang memiliki nilai resistivitas dibawah $1,9 \Omega \mathrm{m}$, warna hijau muda dengan nilai resistivitas $2,3 \Omega \mathrm{m}$ dan warna merah dengan nilai resistivitas $3,6 \Omega \mathrm{m}$. untuk penampang timur-barat yaitu:

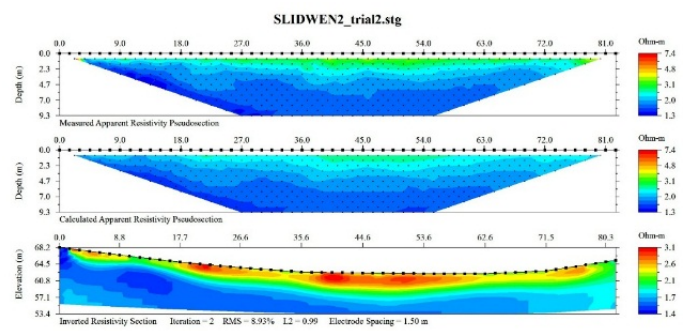

Gambar 9 Tampilan hasil pengolahan lintasan 3 dengan AGI Earthlmager 2D

Pada lintasan 3 digunakan lintasan sepanjang $82,5 \mathrm{~m}$ dengan arah lintasan N270E. Penampang bawah permukaan yang dihasilkan memiliki tingkat kesalahan sebesar 8,93\% dengan iterasi sebanyak 2 kali. Pada penampang resistivitas bawah permukaan sebenarnya didominasi oleh warna biru yang memiliki nilai resistivitas dibawah $1,7 \Omega \mathrm{m}$, warna hijau muda dengan nilai resistivitas $2,1 \Omega \mathrm{m}$ dan warna merah dengan nilai resistivitas $3,1 \Omega \mathrm{m}$.

\section{Penampang Bidang Gelincir}

Gambar 10 merupakan penampang resistivitas dengan menggunakan filter $2 \Omega \mathrm{m}$ yang dianggap sebagai batas bidang gelincir yang merupakan perbatasan lempung asli dengan lempung lapuk dan juga kontur elevasi dari daerah pengukuran. Dari atas ke bawah merupakan penampang lintasan 1, 2 dan 3, garis hitam pada penampang resistivitas mewakili garis dimana lintasan 1, 2 dan 3 saling berpotongan.

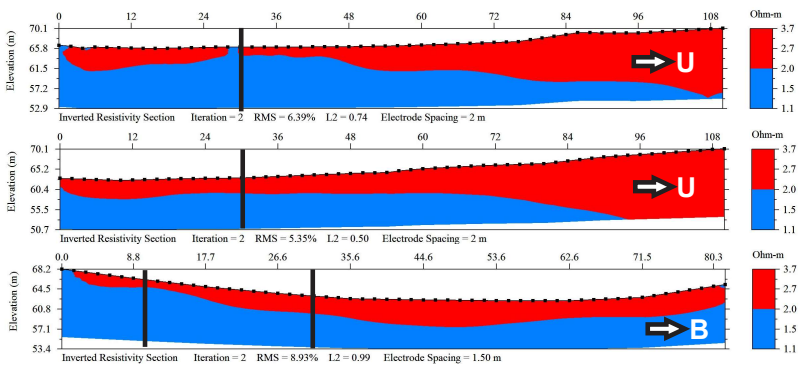

(a) 


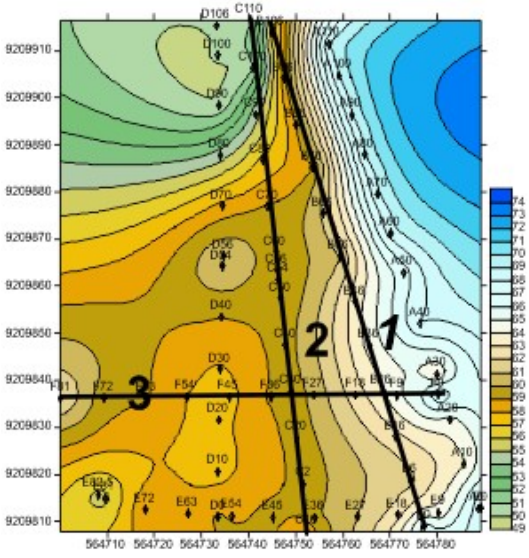

(b)

Gambar 10 Penampang Resistivitas Filter $2 \Omega \mathrm{m}$. Pada gambar (a) merupakan penampang tiap line, pada gambar (b) merupakan peta isoresistvity dengan nilai 2

$\Omega \mathrm{m}$.

Dari data sekunder berupa data geologi dan data topografi daerah Nglajo, diketahui bahwa area pengukuran tersusun pada Formasi Lidah yang berupa Batulempung, bersisipan dengan Batugamping dan Batupasir. Dan pada pengamatan visual secara langsung di lapangan, litologi permukaan daerah pengukuran terdiri atas tanah lempung. Berdasarkan tinjauan pustaka (Telford, 1990) yang didapatkan, lempung memiliki nilai resistivitas 1-100 $\Omega \mathrm{m}$.

Terlihat beberapa ciri-ciri terjadinya gelincir yang terjadi pada daerah pengukuran, ditemukan adanya tambalan aspal yang pada jalan aspal disebelah timur daerah penelitian, yang mana tambalan aspal ini dilakukan terus-menerus tiap tahunnya. Dan hal ini merupakan sebuah tanda bahwa pada lokasi yang ada tersebut terjadi adanya gelincir dengan lebar sepanjang 36 meter. Dan terdapat pula ciri lain dimana pagar yang terletak 18 meter dari lintasan 1 menunjukkan adanya tarikan yang menuju ke arah lokasi penelitian yang menyebabkan miringnya pagar kearah daerah pengukuran. Dua hal tersebut menunjukkan bahwa bahwa longsoran yang terjadi pada daerah pengukuran memiliki kecepatan yang rendah.

Pada lintasan 1, bidang gelincir terjadi sepanjang 0-44 meter. Pada lintasan 2, bidang gelincir terjadi sepajang 0-60 meter. Pada lintasan 3 , bidang gelincir terjadi pada 0-50 meter.
Dengan menggunakan data hasil digitasi bidang gelincir dengan data topografi pada area bidang gelincir, maka dapat digunakan untuk mengetahui kedalaman bidang gelincir untuk tiap lintasan sebagai berikut

- Pada lintasan 1 memiliki kedalaman bidang gelincir 1-4 meter.

- Pada lintasan 2 memiliki kedalaman bidang gelincir 3,5-5,8 meter.

- Pada lintasan 3 memiliki kedalaman bidang gelincir 1,7 hingga 4,8 meter.

Dari hasil pembahasan yang sudah dilakukan berikut adalah ilustrasi bidang gelincir yang terjadi pada daerah penelitian terdapat pada Gambar 11.

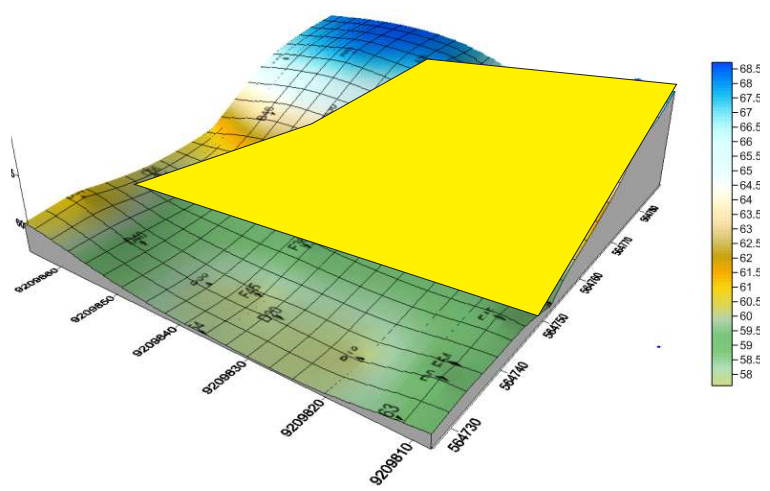

Gambar 11 Ilustrasi Bidang Gelincir

\section{PENUTUP}

\section{Simpulan}

Berdasarkan penelitian yang telah dilaksanakan dapat diambil kesimpulan sebagai berikut :

1. Jenis longsoran yang terjadi pada daerah Nglajo adalah berupa rayapan (Creeping)

2. Terdapat bidang gelincir yang berbentuk trapesium yang melebar kebawah dari arah lintasan 1 ke arah lintasan 3

3. Bidang gelincir pada daerah pengukuran memiliki kedalaman bervariasi antara 1 meter hingga 5,8 meter.

\section{Saran}

Dari penelitian yang sudah dilakukan, terdapat beberapa rekomendasi yang dapat diambil yaitu : apabila akan dilakukan pembuatan bangunan pada area rayapan (pada bagian yang memiliki bidang gelincir) maka pembuatan pondasi harus lebih dalam daripada bidang gelincir. Dan apabila ingin mengurangi kerugian dari perbaikan jalan aspal, 
dapat dilakukan pengerukan tanah lapuk yang ada hingga ke dalam bidang gelincir dan dilakukan penimbunan tanah uruk yang tidak gampang tergelincir.

\section{Ucapan Terima kasih}

Penulis mengcapkan terima kasih kepada PPSDM Migas Cepu sebagai tempat kerja praktek dalam akuisis data hingga interpretasi dan dukungan dosen pembimbing bapak Dr. Ayi Syaeful Bahri, S.Si., MT yang telah membimbing penulis hingga tulisan/jurnal ini selesai.

\section{DAFTAR PUSTAKA}

Fralama. 2017. File:Dispositivo_wenner.svg. Retrieved from commons.wikimedia.org: https://commons.wikimedia.org/wiki/File\%3AD ispositivo_wenner.svg

Loke, M. 2015. Tutorial : 2-D and 3-D Electrical Imaging Surveys. Malaysia: M.H. Loke.

Pringgoprawiro, H., \& Sukido. 2012. Peta Lembar Bojonegoro, Jawa Timur.

Reynolds, J. M. 2011. An Introduction to Applied and Environmental Geophysics. Chichester: WileyBlackwell.

Telford, W., Geldart, L., \& Sheriff, R. 1990. Applied Geophysic Second Edition. Cambridge University Press.

Utama, W., R, J.P.G.N., Agustin, A.D., 2016. Identifikasi Letak dan Kedalaman Cracks pada Bidang Longsor Menggunakan Metode Resistivitas 2D Konfigurasi Wenner-Schlumberger Studi Kasus Kecamatan Selorejo, Blitar. J. Geosaintek 2, 195-200. 